\title{
EFFECTS OF THE REPLACEMENT OF WHEAT FLOUR WITH CRICKET POWDER ON THE CHARACTERISTICS OF MUFFINS
}

\author{
Paulina Pauter, Maria Różańska, Paulina Wiza, Sandra Dworczak, Natalia Grobelna, \\ Paulina Sarbak, Przemysław Ł. Kowalczewski ${ }^{\bowtie}$
}

Institute of Food Technology of Plant Origin, Poznań University of Life Sciences Wojska Polskiego 31, 60-624 Poznań, Poland

\begin{abstract}
Background. Cricket powder (CP) is a cheap and valuable source of protein, unsaturated fatty acids and dietary fiber, as well as vitamins and minerals such as iron and calcium, which makes it useful for the enrichment of bakery products.

Material and methods. The ash, fat, moisture and protein contents of enriched muffins were analyzed according to PN-EN ISO and AACC methods. The proximate carbohydrate content was estimated by subtracting the total fat, protein, ash and moisture content from $100 \%$ of food composition. The color of the muffins was measured in the CIE L*a*b* scale using a Chroma Meter CR-410. A TA.XTplus texture analyzer was used to perform texture profile analysis.

Results. The protein content in muffins enriched with increased CP in samples with $5 \%$ and $10 \% \mathrm{CP}$ addition, and the carbohydrate content reduced as the percentage of CP increased. Results of texture analysis indicated that the use of $\mathrm{CP}$ as an additive caused a significant decrease in the hardness, springiness, chewiness and resilience of the obtained muffins. There were no changes in cohesiveness. With increasing amounts of CP, the value of lightness $\left(L^{*}\right)$ decreased, while the green/red $\left(a^{*}\right)$ and blue/yellow $\left(b^{*}\right)$ color balances were shifted towards green and blue respectively. The results of consumer acceptance tests showed that control muffins and muffins with $2 \% \mathrm{CP}$ did not significantly differ from each other.

Conclusion. Taking into account the slight changes in color and textural properties, cricket powder can be used for the enrichment of muffins with protein without reducing the sensory attractiveness of the product obtained.
\end{abstract}

Keywords: muffins, cricket powder, protein enrichment, texture, consumer acceptance

\section{INTRODUCTION}

Sweets, despite dietitians' recommendations to limit the intake of sugar and fat, are the most commonly consumed snacks (Drewnowski et al., 1998; Rosales-Soto et al., 2012). As a response to growing consumer interest in healthy nutrition, the food industry is increasingly focused on designing foods with reduced sugar content. Muffins are one of the most popular high-calorie snack products consumed worldwide.
Wheat flour, sugar, oil, eggs and milk are the main ingredients of muffins (Sanz et al., 2009). Due to their ready-to-eat nature, soft texture and taste, they are attractive to consumers. However, the nutritional value of wheat proteins is limited due to their low content of essential amino acids, i.e. lysine (Pencharz et al., 2016; Sozer et al., 2017).

\footnotetext{
®przemyslaw.kowalczewski@up.poznan.pl
} 
Muffins are often used as a matrix for the introduction of various nutrients, such as protein and antioxidants (Struck et al., 2016; Mildner-Szkudlarz et al., 2016; 2015). The use of protein enrichment, on the one hand, reduces the sugar content of the product, but, on the other hand, it may also have a significant impact on its textural properties (Mariotti et al., 2009; Ronda et al., 2011). Cricket powder may be used as a protein-rich additive. It should be pointed out that it is cheap and easy to produce, and is considered a good source of dietary protein (Megido et al., 2015).

Insects have been consumed for a long time, especially in Africa, Latin America and Australia (Ramos-Elorduy, 1997). Crickets are a valuable source of protein, unsaturated fatty acids, dietary fiber, vitamins and minerals (Ayieko et al., 2016; Megido et al., 2015). Cricket powder obtained from these insects is characterized by high protein content (about 60-70\%), a lack of carbohydrates, and high iron and calcium content (Ayieko et al., 2016). In addition, it is a gluten-free raw material, so it can be also used for the production of food for people with celiac disease. A FAO report explicitly recommends the use of insects as a source of easily digestible protein, especially in the face of rapid population growth in the world and the growing difficulty of providing sufficient food (van Huis, 2013). Some European countries have regulated the production of insect-based foods before, but from $1^{\text {st }}$ January 2018, insects, as well as their parts, were officially released for sale as a so-called "novel food". These products are subject to pre-market authorization before being made available for sale. Changes to the law in the EU regarding the admission of insects production for consumption have created new opportunities to use this source of protein $(\mathrm{C} / 2017 / 8878)$.

The aim of this work was to evaluate the influence of cricket powder on the nutritional value, textural properties and consumer acceptance of muffins enriched with it.

\section{MATERIALS AND METHODS}

\section{Materials}

Wheat flour (type 500) was obtained from a commercial mill (GoodMills Polska Sp. z o.o., Poland). Rapeseed oil, powdered sugar, whole milk, baking powder and eggs were purchased from a local market.
The cricket powder (CP), bought from Crunchy Critters (United Kingdom), contained $56.8 \%$ protein, $29.3 \%$ fat, $5.5 \%$ carbohydrates and $2.3 \%$ fiber. All chemicals used were of analytical grade.

\section{Muffins preparation}

The muffin formulation contained the ingredients typically used for muffin preparation: $37.00 \%$ wheat flour, $11.10 \%$ rapeseed oil, $12.32 \%$ powdered sugar, $14.80 \%$ whole milk, $0.74 \%$ baking powder and $24.04 \%$ eggs. Control muffins (denoted as $\mathrm{C}$ in the text) were prepared without the addition of CP. For our study, CP was incorporated into the muffins at 2, 5 and $10 \%$ $(\mathrm{w} / \mathrm{w})$ by replacing an equivalent amount of wheat flour in the muffin mixture, and were labelled CPM1, CPM2 and CPM3 respectively. The ingredients were mixed with a KitchenAid (model 5KPM5EWH, KitchenAid, USA). The egg whites and sugar were beaten into a stiff foam and then the egg yolks, milk and rapeseed oil were added. Each of the four muffin formulations, consisting of refined white wheat flour and $\mathrm{CP}$ in different proportions, were added to the prepared dough and gently mixed. The dough $(70 \mathrm{~g})$ was placed into paper muffin cups and baked in a pre-heated oven (model condo, MIWE Michael Wenz GmbH, Germany) at $180^{\circ} \mathrm{C}$ for $15 \mathrm{~min}$. The muffins were then cooled to room temperature and packed in polypropylene pouches.

\section{Proximate composition analysis of muffins}

Total nitrogen was determined by the Kjeldahl method, according to PN-EN ISO $20483(N=6.25)$, ash content was determined according to PN-EN ISO 2171 and total fat content was determined according to AACC 30-25.01. The moisture content was analyzed according to AACC 44-19.01. The proximate carbohydrate content was estimated by subtracting the total fat, protein, ash and moisture content from $100 \%$. Moreover, the energy value $[\mathrm{kcal} / 100 \mathrm{~g}]$ was calculated with the following formula: energy value $=$ $4 \times$ protein $[\%]+4 \times$ carbohydrate $[\%]+9 \times$ fat $[\%]$.

\section{Color measurements}

The color of the muffins was measured using a Chroma Meter CR-410 (Konica Minolta Sensing Inc., Tokyo, Japan). Differences in color were recorded in the CIE L*a*b* scale in terms of lightness $\left(L^{*}\right)$ and color 
( $a^{*}$ - redness, $b^{*}-$ yellowness). Color measurement was repeated 15 times for each sample. Additionally, the total color difference $(\Delta E)$ was calculated using the following formula:

$$
\Delta E=\sqrt{\Delta L^{* 2}+\Delta a^{* 2}+\Delta b^{* 2}}
$$

where $\Delta L^{*}, \Delta a^{*}$ and $\Delta b^{*}$ are differences in the $L^{*}, a^{*}$, $b^{*}$ values between the reference sample and the test sample respectively.

\section{Texture analysis}

The texture profile analysis (TPA) of the obtained muffins was performed one day after baking according to method described by Mildner-Szkudlarz et al. (2016) with a slight modification. A TA.XTplus texture analyzer (Stable Micro System Co. Ltd., England) equipped with a $5 \mathrm{~kg}$ load cell and a cylindrical plunger probe of a $35 \mathrm{~mm}$ diameter was used. The measurement was performed at pre-test speed: $1.0 \mathrm{~mm} / \mathrm{s}$, and test speed: $1.7 \mathrm{~mm} / \mathrm{s}$ and strain $40 \%$. The muffins were cut into $25 \mathrm{~mm}$ thick slices (the top and bottom layers were discarded). Texture measurement was repeated 10 times for each sample. During the test, hardness, springiness, cohesiveness, chewiness and resilience were recorded.

\section{Consumer study}

Consumer acceptance analysis was based on a 9-point hedonic line scale (ranging from 1, "dislike very much", to 9, "like very much") according to Villanueva et al. (2000). Forty untrained panelists aged between twenty and fifty-five, recruited on the campus of Poznań University of Life Sciences, were invited to participate in this study. Consumers were asked to evaluate the appearance, taste, flavor, texture and overall rating of the manufactured muffins.

\section{Statistical analysis}

All measurements were repeated three times, unless otherwise stated. One-way analysis of variance (ANOVA) was carried out independently for each dependent variable. Post-hoc Tukey HSD multiple comparison test was used to identify statistically homogeneous subsets at $\alpha=0.05$. Statistical analysis was performed with Statistica 13 software (Dell Software Inc., USA).

\section{RESULTS AND DISCUSSION}

\section{Nutritional value}

Crickets and cricket powder are a good source of nutritionally valuable compounds - proteins, lipids, and, especially, polyunsaturated fatty acids and minerals, such as calcium, iron, or zinc (Ayieko et al., 2016). The substitution of wheat flour with cricket powder changed the nutritional value of the products, due to the high quality and digestibility of protein and the content of essential amino acids (Zielińska et al., 2015). The protein content in muffins enriched with $C P$ significantly increased (starting from the $5 \%$ addition level) with increasing percentage of $\mathrm{CP}$ in the product (Table 1). In CPM3 muffins, an increase in protein content by ca. $5 \%$ was observed relative to the control sample. Global trends in food design favor increased protein content in low sugar products (Anderson et al.,

Table 1. Nutritional value of muffins

\begin{tabular}{lcccccc}
\hline \multicolumn{1}{c}{ Sample } & $\begin{array}{c}\text { Moisture } \\
\%\end{array}$ & $\begin{array}{c}\text { Protein } \\
\%\end{array}$ & Fat, \% & Ash, \% & $\begin{array}{c}\text { Carbohydrate } \\
\%\end{array}$ & $\begin{array}{c}\text { Energy value } \\
\mathrm{kcal} / 100 \mathrm{~g}\end{array}$ \\
\hline $\mathrm{C}$ & $19.40 \pm 1.01^{\mathrm{b}}$ & $11.84 \pm 0.24^{\mathrm{c}}$ & $23.46 \pm 0.74^{\mathrm{bc}}$ & $1.00 \pm 0.14^{\mathrm{b}}$ & $44.29 \pm 0.18^{\mathrm{a}}$ & $435.66 \pm 8.28^{\mathrm{a}}$ \\
$\mathrm{CPM} 1$ & $21.28 \pm 0.52^{\mathrm{ab}}$ & $12.27 \pm 0.18^{\mathrm{c}}$ & $23.64 \pm 0.08^{\mathrm{c}}$ & $1.10 \pm 0.14^{\mathrm{b}}$ & $41.82 \pm 0.49^{\mathrm{b}}$ & $429.12 \pm 1.91^{\mathrm{a}}$ \\
$\mathrm{CPM} 2$ & $21.53 \pm 0.04^{\mathrm{ab}}$ & $14.58 \pm 0.54^{\mathrm{b}}$ & $24.39 \pm 0.17^{\mathrm{b}}$ & $1.33 \pm 0.32^{\mathrm{ab}}$ & $38.17 \pm 0.09^{\mathrm{c}}$ & $430.51 \pm 0.27^{\mathrm{a}}$ \\
CPM3 & $21.96 \pm 0.36^{\mathrm{a}}$ & $16.51 \pm 0.23^{\mathrm{a}}$ & $25.34 \pm 0.75^{\mathrm{a}}$ & $1.65 \pm 0.21^{\mathrm{a}}$ & $34.45 \pm 0.37^{\mathrm{d}}$ & $431.90 \pm 4.35^{\mathrm{a}}$ \\
\hline
\end{tabular}

C, CPM1, CPM2 and CPM3 means muffins with cricket powder at $0 \%, 2 \%, 5 \%$ and $10 \%(\mathrm{w} / \mathrm{w})$, respectively. Mean values in columns denoted by different letters differ statistically significantly $(p<0.05)$. 
2012). Enrichment of bakery products with protein results not only in lowering the carbohydrate content of a product but also increases the overall intake of protein in a person's diet. Gluten-free products in particular are often enriched with protein. As stated by Ziobro et al. (2016), the application of protein rich additives results in greater muffin volume and height because protein is prone to swelling and denaturation at increased temperatures, which helps to form a structure that holds gasses. Moreover, in order to increase the nutritional value of muffins made from wheat flour, soy or chickpea protein have been applied. The former has a high nutritional value (Reinwald et al., 2010), the latter is characterized by high protein digestibility of $76-78 \%$ (Xu et al., 2014). Muffins with soy protein have been found to be highly acceptable to consumers (Padhi et al., 2015). However, allergies to soy are common. Protein from insects has not been found to be allergenic.

Although the proportions of protein and carbohydrates changed, no influence was found on the energy value of the obtained muffins. Moreover, Van Huis (2013) reported that CP contains not only protein or fat, but also minerals. Nevertheless, no changes in fat and ash content in the muffins with $\mathrm{CP}$ were observed.

\section{Color of muffins}

The appearance and color of the product are the key parameters that determine desirability (D'Egidio and Pagani, 1997). Consumers usually perceive darker muffins as healthier and containing more fiber or whole grains. Purlis and Salvadori (2009) indicated that the color of crumb depends on the conditions of the technological process - caramelization and Maillard reactions may take place simultaneously, and both reactions depend on temperature, content of reducing sugars and amino groups. Ronda et al. (2005) proved that changes in the sugar content can also contribute to changes in the color of the products. The use of CP to enrich the muffins with protein caused significant changes in the color of the products (Table 2). Maillard browning occurs when amino acids and reducing sugars are heated, for example during baking. Increased protein content may contribute to easier formation of Maillard reaction products (melanoidins), which are responsible for reducing the lightness of muffins (Michalska et al., 2008; Mildner-Szkudlarz et al., 2015). The lightness $\left(L^{*}\right)$ of muffins is significantly reduced as the percentage of CP increases. Nevertheless, this trend was not noted in all muffin samples. In contrast, CPM1 were lighter than CPM2 and CPM3 muffins. As the color change cannot be analyzed just in terms of lightness, it should be noted that saturation of green and blue increased in all samples. The total color difference $(\Delta E>7)$ value indicates a significant effect of $\mathrm{CP}$ addition on the color of muffins. Instrumental color measurement of color change was in accordance with the results of visual evaluation by consumers.

\section{Texture properties}

The results of textural property analysis (Table 3) clearly indicate that the use of $\mathrm{CP}$ as an additive caused significant changes in the hardness of the obtained muffins. The addition of CP decreased the hardness of the obtained muffins from $42.99 \pm 2.31 \mathrm{~N}$ in $\mathrm{C}$ to $34.46 \pm 3.03,32.27 \pm 1.72$ and $27.73 \pm 0.85 \mathrm{~N}$ in CPM1, CPM2 and CPM3 respectively. Control muffins, with the strongest gluten network, were found to

Table 2. Color determinants and total changes color

\begin{tabular}{lcccc}
\hline \multicolumn{1}{c}{ Sample } & $L^{*}, \%$ & $a^{*}$ & $b^{*}$ & $\Delta E$ \\
\hline C & $62.97 \pm 0.23^{\mathrm{b}}$ & $9.21 \pm 0.14^{\mathrm{a}}$ & $24.06 \pm 0.73^{\mathrm{a}}$ & - \\
CPM1 & $66.49 \pm 0.88^{\mathrm{a}}$ & $5.33 \pm 0.12^{\mathrm{b}}$ & $19.51 \pm 0.27^{\mathrm{b}}$ & 9.81 \\
CPM2 & $60.94 \pm 0.34^{\mathrm{c}}$ & $4.39 \pm 0.14^{\mathrm{c}}$ & $15.76 \pm 0.32^{\mathrm{c}}$ & 15.32 \\
CPM3 & $54.05 \pm 0.50^{\mathrm{d}}$ & $4.28 \pm 0.04^{\mathrm{c}}$ & $12.23 \pm 0.12^{\mathrm{d}}$ & \\
\hline
\end{tabular}

C, CPM1, CPM2 and CPM3 means muffins with cricket powder at $0 \%, 2 \%, 5 \%$ and $10 \%(\mathrm{w} / \mathrm{w})$, respectively. Mean values in columns denoted by different letters differ statistically significantly $(p<0.05)$. 
Pauter, P., Różańska, M., Wiza, P., Dworczak, S., Grobelna, N., Sarbak, P., Kowalczewski, P. Ł. (2018). Effects of the replacement of wheat flour with cricket powder on the characteristics of muffins. Acta Sci. Pol. Technol. Aliment., 17(3), 227-233. http://dx.doi. org/10.17306/J.AFS.2018.0570

Table 3. Results of texture analysis

\begin{tabular}{llllll}
\hline \multicolumn{1}{c}{ Sample } & Hardness, N & Springiness, \% & Cohesiveness & Chewiness & Resilience \\
\hline C & $42.99 \pm 2.31^{\mathrm{a}}$ & $90.15 \pm 1.32^{\mathrm{a}}$ & $0.70 \pm 0.05^{\mathrm{a}}$ & $2775.09 \pm 227.64^{\mathrm{a}}$ & $0.29 \pm 0.02^{\mathrm{a}}$ \\
CPM1 & $34.46 \pm 3.03^{\mathrm{b}}$ & $89.75 \pm 1.39^{\mathrm{a}}$ & $0.68 \pm 0.05^{\mathrm{a}}$ & $2129.76 \pm 58.69^{\mathrm{b}}$ & $0.26 \pm 0.02^{\mathrm{ab}}$ \\
CPM2 & $32.27 \pm 1.72^{\mathrm{bc}}$ & $89.00 \pm 1.75^{\mathrm{ab}}$ & $0.66 \pm 0.04^{\mathrm{a}}$ & $1808.64 \pm 146.24^{\mathrm{bc}}$ & $0.25 \pm 0.03^{\mathrm{ab}}$ \\
CPM3 & $27.73 \pm 0.85^{\mathrm{c}}$ & $87.08 \pm 1.03^{\mathrm{b}}$ & $0.61 \pm 0.07^{\mathrm{a}}$ & $1629.35 \pm 122.55^{\mathrm{c}}$ & $0.22 \pm 0.02^{\mathrm{b}}$ \\
\hline
\end{tabular}

C, CPM1, CPM2 and CPM3 means muffins with cricket powder at $0 \%, 2 \%, 5 \%$ and $10 \%(\mathrm{w} / \mathrm{w})$, respectively. Mean values in columns denoted by different letters differ statistically significantly $(p<0.05)$

be the hardest. While the protein content in the muffins was increased by the addition of $\mathrm{CP}$, the amount of gluten and starch decreased. According to Feili et al. (2013), the hardness of bakery products depends mainly on the amylopectin and amylose contents of the product. With the increase in protein content and reduced starch content, a significant decrease in hardness is observed (Gómez et al., 2003; Martinez-Cervera et al., 2011). Rodríguez-García et al. (2014) also reported that hardness is related to the total air cell volume and volume of crumb. As the size of the gas cell increases, the product has a softer crumb structure. Well-aerated and elastic muffins, with high values of springiness, are perceived as fresh and of high quality (Sanz et al., 2009). Decreases in springiness and resilience were noted only in the case of muffins with $10 \%$ $\mathrm{CP}$ additive. Chewiness, which is primarily associated with the difficulty of chewing before swallowing, is an additional key texture parameter (Martínez-Cervera et al., 2012). The value of chewiness significantly decreased as the percentage of $\mathrm{CP}$ addition increased. Moreover, no significant differences in cohesiveness were found between the control and the samples with added $\mathrm{CP}$.

\section{Consumer acceptance}

High nutritional value and health-promoting properties must be accompanied by sensory attractiveness (Sun-Waterhouse and Wadhwa, 2013) to create a viable product. Taste, smell and appearance are some of the most important factors that influence a consumer's decision to purchase. Data presented in Figure 1 shows that the control muffins had the highest appearance rating, compared to all the enriched muffins.
The addition of CP caused changes in appearance and color that consumers perceived as unattractive. This suggests that the enriched muffins were possibly overly dark. However, the addition of CP increased the taste and texture scores. The CPM1 and CPM2 muffins had a significantly higher rating (7.6 and 7.5 for CPM1 and CPM2, respectively) for texture than the control (6.2), as well as for taste (7.1, 7.0, 6.9 and 6.2 for CPM1, CPM2, CPM3 and C respectively). The addition of $\mathrm{CP}$, however, caused a noticeable "off" flavor which was negatively perceived by the consumers. Nevertheless, based on the results of the overall rating, it might be concluded that a $2 \%(\mathrm{w} / \mathrm{w})$ substitution of wheat flour with $\mathrm{CP}$ would be acceptable to consumers.

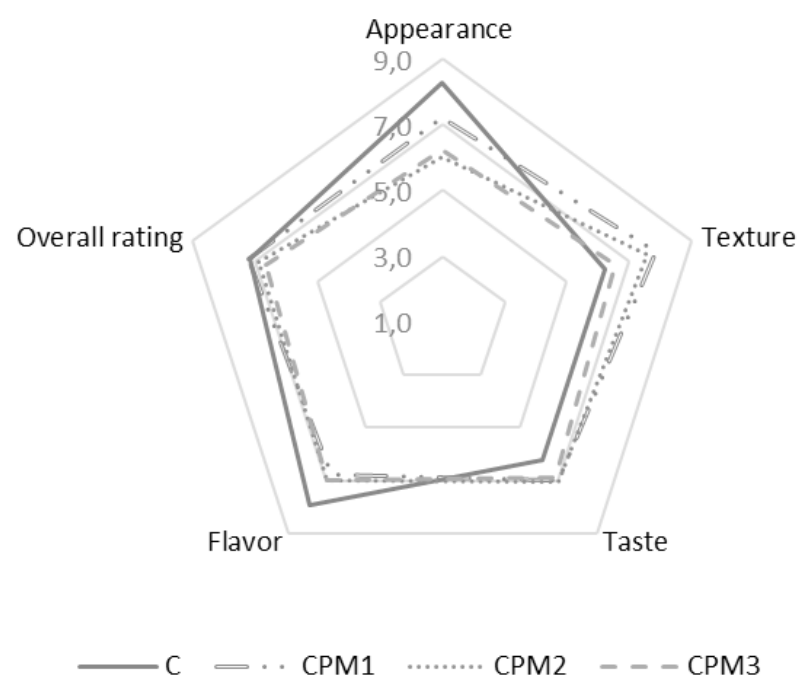

Fig. 1. Results of consumer acceptance analysis 


\section{CONCLUSION}

It was found that the addition of $\mathrm{CP}$ increased the content of protein and ash and decreased the carbohydrate content of the product. Despite the changes in the proportions of protein and carbohydrate, no effect on energy value was noted. Changes in textural properties were also observed. The hardness, springiness, chewiness and resilience of muffin crumb were significantly reduced as the percentage of $\mathrm{CP}$ increased. Enrichment with cricket powder caused a reduction in the lightness of muffins. Reductions in red and yellow color saturation were also observed. Nevertheless, the results of consumer acceptance tests indicate that muffins with a small amount of added CP were considered as attractive as conventional products, and, as a source of protein, could also be a solution to hunger-related problems and undernourishment.

\section{REFERENCES}

AACC (1999a). AACC International Approved Methods of Analysis. 11th ed. AACCI Method 44-19.01. MoistureAir-Oven Method, Drying at $135^{\circ}$. Approved November 3, 1999. St. Paul, MN, USA: AACC Intern. http://doi. org/10.1094/AACCIntMethod-44-19.01

AACC (1999b). AACC International Approved Methods of Analysis. 11th ed. AACCI Method 30-25.01. Crude Fat in Wheat, Corn, and Soy Flour, Feeds, and Mixed Feeds. Approved November 3, 1999. St. Paul, MN, USA: AACC Intern. http://doi.org/10.1094/ AACCIntMethod-30-25.01

Anderson, G. H., Foreyt, J., Sigman-Grant, M., Allison, D. B. (2012). The use of low-calorie sweeteners by adults: Impact on weight management. J. Nutr., 142(6), 1163s1169s. https://doi.org/10.3945/jn.111.149617

Ayieko, M. A., Ogola, H. J., Ayieko, I. A. (2016). Introducing rearing crickets (gryllids) at household levels: Adoption, processing and nutritional values. J. Ins. Food Feed, 2(3), 203-211. https://doi.org/10.3920/JIFF2015.0080

$\mathrm{C} / 2017 / 8878$. Commission Implementing Regulation (EU) 2017/2470 of 20 December 2017 establishing the Union list of novel foods in accordance with Regulation (EU) 2015/2283 of the European Parliament and of the Council on novel foods. OJ L 351/72, 30.12.2017.

D’Egidio, M. G., Pagani, M. A. (1997). Effect of different stages of durum wheat chain on pasta color. Ital. Food Bever. Technol., 10, 17-20.
Drewnowski, A., Nordensten, K., Dwyer, J. (1998). Replacing sugar and fat in cookies: impact on product quality and preference. Food Qual. Pref., 9, 13-20.

Feili, R., Zzaman, W., Abdullah, W. N. W., Yang, T. A. (2013). Physical and sensory analysis of high fiber bread incorporated with jackfruit rind flour. Food Sci. Technol., 1(2), 30-36.

Gómez, M., Ronda, F., Blanco, C. A., Caballero, P. A., Apesteguia, A. (2003). Effect of dietary fiber on dough rheology and bread quality. Eur. Food Res. Technol., 216, 51-56. https://doi.org/10.1007/s00217-002-0632-9

Kowalczewski, P., Lewandowicz, G., Makowska, S., Knoll, I., Błaszczak, W., Białas, W., Kubiak, P. (2015). Pasta fortified with potato juice: Structure, quality, and consumer acceptance. J. Food Sci., 80(6), S1377-S1382. https://doi.org/10.1111/1750-3841.12906

Mariotti, M., Lucisano, M., Pagani, M. A., Ng, P. K. W. (2009). The role of corn starch, amaranth flour, pea isolate, and Psyllium flour on the rheological properties and the ultrastructure of gluten-free doughs. Food Res. Int., 42, 963-975. https://doi.org/10.1016/j. foodres.2009.04.017

Martinez-Cervera, S., Salvador, A., Muguerza, B., Moulay, L., Fiszman, S. M. (2011). Cocoa fibre its application as a fat replacer in chocolate muffins. Food Sci. Technol., 44, 729-736.

Martínez-Cervera, S., Sanz, T., Salvador, A., Fiszman, S. M. (2012). Rheological, textural and sensorial properties of low-sucrose muffins reformulated with sucralose/ polydextrose. LWT - Food Sci. Technol., 25, 213-220. https://doi.org/10.1016/j.lwt.2011.08.001

Megido, R. C., Alabi, T., Nieus, C., Blecker, Ch., Danthine, S., Bogaert, J., ..., Francis F. (2015). Optimisation of a cheap and residentialsmall-scale production of edible crickets withlocal by-products as an alternative protein-richhuman food source in Ratanakiri Province, Cambodia. J. Sci. Food Agric., 96, 627-632. http://doi. org/10.1002/jsfa.7133

Michalska, A., Amigo-Benavent, M., Zieliński, H., del Castillo, M. D. (2008). Effect of bread making on formation of Maillard reaction products contributing to the overall antioxidant activity of rye bread. J. Cereal Sci., 48(1), 123-132. https://doi.org/10.1016/j.jcs.2007.08.012

Mildner-Szkudlarz, S., Bajerska, J., Górnaś, P., Segliņa, D., Pilarska, A., Jesionowski, T. (2016). Physical and bioactive properties of muffins enriched with raspberry and cranberry pomace powder: A promising application of fruit by-products rich in biocompounds. Plant Foods Hum. Nutr., 71(2), 165-173. https://doi.org/10.1007/ s11130-016-0539-4 
Pauter, P., Różańska, M., Wiza, P., Dworczak, S., Grobelna, N., Sarbak, P., Kowalczewski, P. Ł. (2018). Effects of the replacement of wheat flour with cricket powder on the characteristics of muffins. Acta Sci. Pol. Technol. Aliment., 17(3), 227-233. http://dx.doi. org/10.17306/J.AFS.2018.0570

Mildner-Szkudlarz, S., Siger, A., Szwengiel, A., Bajerska, J. (2015). Natural compounds from grape by-products enhance nutritive value and reduce formation of CML in model muffins. Food Chem., 172(1), 78-85. https://doi. org/10.1016/j.foodchem.2014.09.036

Padhi, E. M. T., Ramdath, D. D., Carson, S. J., Hawke, A., Blewett, H. J., Wolever, T. M. S., ..., Duncan, A. M. (2015). Liking of soy flour muffins over time and the impact of a health claim on willingness to consume. Food Res. Int., 77, 491-497.

Pencharz, P. B., Elango, R., Wolfe, R. R. (2016). Recent developments in understanding protein needs - How much and what kind should we eat? Appl. Physiol. Nutr. Metab., 41, 577-580. http://doi.org/10.1139/apnm-2015-0549

PN-EN ISO 20483:2013. Cereals and pulses - Determination of the nitrogen content and calculation of the crude protein content - Kjeldahl method. Warszawa: PKN.

PN-EN ISO 2171:2010. Cereals, pulses and by-products Determination of ash yield by incineration. Warszawa: PKN.

Purlis, E., Salvadori, V. (2009). Modeling the browning of bread during baking. F. Res. Inter., 42, 865-870. https:// doi.org/10.1016/j.foodres.2009.03.007

Ramos-Elorduy, J. (1997). Insects: A sustainable source of food? Ecol. Food Nutr., 36(2-4), 247-276. https://doi.or $\mathrm{g} / 10.1080 / 03670244.1997 .9991519$

Reinwald, S., Akabas, S. R., Weaver, C. M. (2010). Whole versus the piecemeal approach to evaluating soy. J. Nutr., 140, 2335S-2343S.

Rodríguez-García, J., Sahi, S. S., Hernando, I. (2014). Functionality of lipase and emulsifiers in low-fat cakes with inulin. LWT - Food Sci. Technol., 58, 173-182. https:// doi.org/10.1016/j.lwt.2014.02.012

Ronda, F., Gomes, M., Blanco, C. A., Caballero, P. A. (2005). Effects of polyols and nondigestible oligosaccharides on the quality of sugar-free sponge cakes. Food Chem., 90, 549-55. https://doi.org/10.1016/j. foodchem.2004.05.023

Ronda, F., Oliete, B., Gómez, M., Caballero, P. A., Pando, V. (2011). Rheological study of layer cake batters made with soybean protein isolate and different starch sources. J. Food Eng., 102, 272-277. https://doi.org/10.1016/j. jfoodeng.2010.09.001
Rosales-Soto, M. U., Powers, J. R., Alldredge, J. R. (2012). Effect of mixing time, freeze-drying and baking on phenolics, anthocyanins and antioxidant capacity of raspberry juice during processing of muffins. J. Sci. Food Agric., 92, 1511-1518. https://doi.org/10.1002/jsfa.4735

Sanz, T., Salvador, A., Baixauli, R., Fiszman, S. M. (2009). Evaluation of four types of resistant starch in muffins. II. Effects in texture, colour and consumer response. Eur. Food Res. Technol., 229, 197-204. https://doi. org/10.1007/s00217-009-1040-1

Sozer, N., Nordlund, E., Ercili-Cura, D., Poutanen, K. (2017). Cereal side-streams as alternative protein sources. Cereal Foods World, 62(4), 132-137. https://doi. org/10.1094/CFW-62-4-0132

Struck, S., Gundel, L., Zahn, S., Rohm, H. (2016). Fiber enriched reduced sugar muffins made from iso-viscous batters. LWT - Food Sci. Technol., 65, 32-38. https:// doi.org/10.1016/j.lwt.2015.07.053

Sun-Waterhouse, D., Wadhwa, S. S. (2013). Industry-relevant approaches for minimising the bitterness of bioactive compounds in functional foods: a review. Food Bioproc. Tech., 6, 607-627. https://doi.org/10.1007/ s11947-012-0829-2

van Huis, A. (2013). Potential of insects as food and feed in assuring food security. Ann. Rev. Entomol., 58, 563-583. https://doi.org/10.1146/annurev-ento-120811-153704

Villanueva, N. D. M., Petenate, A. J., Da Silva, M. A. A. P. (2000). Performance of three affective methods and diagnosis of the ANOVA model. Food Qual. Prefer., 11, 363370. https://doi.org/10.1016/S0950-3293(00)00006-9

$\mathrm{Xu}$, Y., Thomas, M., Bhardwaj, H. L. (2014). Chemical composition, functional properties and microstructural characteristics of three kabuli chickpea (Cicer arietinum L.) as affected by different cooking methods. Int. J. Food Sci. Technol., 49, 1215-1223.

Zielińska, E., Baraniak, B., Karaś, M., Rybczyńska, K., Jakubczyk, A. (2015). Selected species of edible insects as a source of nutrient composition. Food Res. Int., $77(3), 460-466$.

Ziobro, R., Juszczak, L., Witczak, M., Korus, J. (2016). Non-gluten proteins as structure forming agents in gluten free bread. J. Food Sci. Technol., 53(1), 571-580. 